\title{
Kemampuan Pemecahan Masalah Matematis dalam Menyelesaikan Soal Cerita Ditinjau dari Langkah- Langkah Polya Materi Bangun Ruang Madrasah Ibtidaiyah
}

\author{
Lely Alfiandari ${ }^{1}, \operatorname{Alman}^{2} \&$ Sahidi $^{3}$ \\ Prodi PGSD, Universitas Pendidikan Muhammadiyah Sorong, Indonesia \\ $\bowtie$ E-mail: 1elyalfiandari02@gmail.com
}

\begin{abstract}
Abstrak
Penelitian ini bertujuan untuk menganalisis kemampuan pemecahan masalah matematis peserta didik dalam menyelesaikan soal cerita ditinjau dari langkah-langkah polya pada materi bangun ruang kelas VI. Jenis penelitian ini adalah deskriptif kualitatif dengan Teknik pengumpulan data adalah tes, wawancara, dan dokumentasi. Subjek penelitian dipilih melalui teknik purposive sampling sehigga diperoleh peserta didik Kelas VI MI Sains Al-Hidayah dengan jumlah 6 orang. Analisis data meliputi pengumpulan data, reduksi, penyajian, dan penarikan kesimpulan. Hasil penelitian diperoleh bahwa kemampuan pemecahan masalah matematis peserta didik dalam kategori tinggi adalah mampu memahami masalah, mampu merencanakan penyelesaian, mampu menyelesaikan masalah, tetapi mengalami sedikit kesulitan dalam mengecek kembali. Kemampuan pemecahan kategori sedang yakni mampu memahami masalah yang diketahui dan ditanyakan dalam soal, kurang mampu merencanakan masalah, meskipun salah dalam melaksanakan rencana penyelesaian namun tidak melakukan kesalahan perhitungan, dan belum mampu dalam melihat kembali hasil penyelesaiannya. Sedangkan kemampuan pemecahan masalah kategori rendah belum mampu memahami masalah, merencanakan penyelesaian, melaksanakan rencana penyelesaian dan belum mampu mengecek kembali hasil yang diperoleh. Kesimpulannya adalah kemampuan pemecahan masalah matematis peserta didik dalam menyelesaikan soal cerita ditinjau dari langkah-langkah polya dianalisis dengan tiga kemampuan yakni Tinggi, Sedang dan rendah.
\end{abstract}

Kata Kunci: Pemecahan Masalah Matematis; Polya; Bangun Ruang.

\begin{abstract}
This study aims to analyze the problem solving of students' friends in solving story problems from polya's steps in the sixth grade classroom building material. This type of research is descriptive qualitative with data collection techniques are tests, interviews, and documentation. The research subjects were selected through purposive sampling technique so that 6 students were obtained in Class VI MI Sains Al-Hidayah. Data analysis includes data collection, reduction, presentation, and drawing conclusions. The results showed that students' mathematical problem solving in the high category was able to understand, able to solve, able to solve problems, but had a little difficulty in checking again. The ability to solve categories is to understand the problems that are known and are being studied, are less able to plan problems, even though they are wrong in carrying out the settlement plan but do not make calculation errors, and have not been able to see the results of the solution. Meanwhile, the ability to solve problems in the low category has not been able to understand the problem, plan a solution, carry out a settlement plan and has not been able to re-check the results obtained. The conclusion is the ability to solve mathematical problems of students in solving story problems in terms of polya steps analyzed with abilities namely High, Medium and Low.
\end{abstract}

Keywords: Mathematical Problem Solving; Polya; Geometry 


\section{PENDAHULUAN}

Sekolah Dasar merupakan salah satu komponen penting dalam sistem pendidikan nasional. Berdasarkan Undang-Undang Republik Indonesia Nomor 20 Tahun 2003 tentang Sistem Pendidikan Nasional (UU Sisdiknas) pendidikan dasar mencakup SD/MI, SMP/MTs. Pendidikan formal ini berlangsung selama 6 tahun dan sangat menentukan pembentukan karakter peserta didik kedepannya. Pembentukan karakter ini dilakukan secara bertahap dan disesuaikan dengan porsi daya tangkap peserta didik. Selain pembentukan karakter, mereka juga akan mendapatkan ilmu pengetahuan dan penanaman nilai-nilai yang nantinya akan berguna dalam kehidupannya. Pada masa ini peserta didik akan diajarkan berbagai ilmu pengetahuan atau mata pelajaran yang relevan dengan tingkat usianya dan tentunya yang menunjang untuk kelanjutan pendidikannya ke jenjang yang lebih tinggi (Sugiyatmi, 2012).

Mata pelajaran yang wajib di pelajari peserta didik pada jenjang ini adalah matematika. Matematika merupakan ilmu yang memiliki peranan penting dalam membentuk pola pikir peserta didik (Siagian, 2016), sehingga mereka dituntut memiliki kemampuan matematis guna sebagai alat pemecahan masalah. Pemecahan masalah sebagai sesuatu hal yang penting dalam pembelajaran matematika menuntut peserta didik dapat berpikir kreatif untuk mengerjakan soal-soal terutama bagaimana peserta didik menyelesaikan soal cerita matematika.

Menurut Sugondo dalam (Nafi'an, 2011) soal cerita matematika merupakan soal-soal yang menggunakan bahasa verbal dan umumnya berhubungan dengan kegiatan sehari-hari. Soal cerita tidak semudah ketika peserta didik menyelesaikan soal berbentuk bilangan. Peserta didik tidak hanya dituntut untuk memiliki keterampilan dalam berhitung saja, namun memperhatikan proses penyelesaiannya juga (Utami, et al 2018). Diharapkan peserta didik menyelesaikan soal cerita melalui tahap demi tahap sehingga guru mampu menganalisis kemampuan yang telah mereka miliki terutama pemahaman peserta didik terhadap konsep yang digunakan dalam menyelesaikan soal cerita yang diberikan. Namun, pada kenyataannya peserta didik sering mengalami kesulitan untuk memahami apa yang dimaksud oleh soal, apa yang diketahui dan ditanyakan oleh soal, berlanjut pada bagaimana atau cara apa menyelesaikan soal, begitu pula dalam mengomunikasi-kan temuan/hasil. Apabila peserta didik tidak mampu memahami masalah tentu akan kesulitan pada tahap selanjutnya yang meliputi kemampuan merencanakan, menyelesaikan, serta memeriksa kembali.

Hal ini sesuai dengan tahapan penyelesaian soal pemecahan masalah menurut Polya (1973: 5), bahwa sebelum tahap merencanakan, menyelesaikan, serta memeriksa kembali, terlebih dahulu peserta didik harus mampu memahami masalah yang ada pada soal. Hal ini menunjukkan pentingnya guru untuk membiasakan peserta didik menyelesaikan latihan soal berupa soal cerita.

Geometri sangat erat kaitannya dengan suatu permasalahan dalam kehidupan seharihari. Pada pembelajaran geometri diperlukan pemikiran dan penalaran yang kritis serta kemampuan abstraksi logis (Dewi, 2013). Pengenalan geometri di sekolah dasar (SD) mempunyai tujuan dasar untuk memberikan suatu kesempatan kepada murid untuk menganalisis lebih jauh dunia tempat hidupnya, serta memberikan sejak dini landasan berupa konsep-konsep dasar dan 
peristilahan yang diperlukan untuk studi lebih lanjut. Pemahaman konsep dasar sangat menentukan keberhasilan belajar selanjutnya (Mursalin, 2016). Pada dasarnya, materi geometri akan mudah dipahami oleh peserta didik dibanding dengan cabang matematika yang lain (Wardhani, 2015). Namun pada kenyataannya, kemampuan peserta didik dalam memahami materi geometri sangatlah rendah sehingga peserta didik kurang mampu menyelesaikan soal-soal cerita geometri terutama tentang bangun ruang. Saat guru memberikan soal bangun ruang yang hanya menerapkan rumus, peserta didik dengan mudah mengerjakan. Namun saat guru memberikan soal cerita tentang materi bangun ruang yang berkaitan dengan kehidupan sehari-hari, peserta didik mengalami kesulitan.

Berdasarkan pernyataan guru mata pelajaran matematika kelas VI MI Sains Al Hidayah Kota Sorong, kemampuan peserta didik dalam memecahkan masalah berupa penyelesaian soal-soal cerita dalam kehidupan sehari-hari masih rendah. Beliau berpendapat bahwa peserta didik cenderung malas membaca soal cerita, sehingga peserta didik kesulitan menyelesaikan soal. Peserta didik lebih mudah menyelesaikan soal matematika yang hanya menerapkan rumusrumus saja tanpa harus membaca soal cerita. Misalnya, pada materi bangun ruang kubus peserta didik lebih mudah menyelesaikan soal apabila pada soal sudah disediakan gambar bangun ruang kemudian peserta didik hanya menggunakan rumus-rumus saja.

Peserta didik kelas VI MI Sains Al Hidayah Kota Sorong justru beranggapan bahwa soal-soal dalam bentuk soal cerita selalu sulit untuk dipahami hal ini dikarenakan kurangnya penjelasan dari guru bagaimana cara atau model-model alternatif dalam menyelesaikan soal-soal cerita yang berhubungan dengan pembelajaran matematika khususnya materi bangun ruang.

Sehubungan dengan hal-hal yang terjadi tentang kemampuan menyelesaikan soal-soal cerita matematika, maka guru sangat berperan penting dan aktif untuk menciptakan peserta didik yang memiliki kemampuan menyelesaikan soal-soal cerita matematika yang baik, sehingga memperoleh hasil belajar yang memuaskan dan tujuan pembelajaran yang ditetapkan tercapai. Namun pada kenyataannya, peran guru dalam mewujudkan peserta didik yang mampu memecahkan masalah kurang dalam pembelajaran matematika, guru hanya menekankan pemahaman konsep matematika dan penghafalan rumus-rumus matematika saja, guru yang aktif memberikan materi sedangkan peserta didik pasif. Hal ini menyebabkan kemampuan peserta didik dalam memecahkan masalah berupa penyelesaian soal-soal cerita dalam kehidupan sehari-hari rendah.

Berdasarkan permasalahan diatas, maka peneliti tertarik untuk menggali kemampuan pemecahan masalah matematis peserta didik dalam menyelesaikan soal cerita ditinjau dari langkah-langkah polya pada materi bangun ruang kelas VI SD.

\section{METODE PENELITIAN}

Jenis penelitian ini adalah deskriptif kualitatif. Pendekatan dalam penelitian ini menggunakan pendekatan kualitatif. Teknik pengumpulan data yang digunakan adalah tes, wawancara, dan dokumentasi. Subjek penelitian adalah peserta didik Kelas VI MI Sains Al-Hidayah Kota Sorong dengan jumlah 6 orang. Subjek penelitian dipilih melalui teknik purposive sampling yang kemudian dibagi dalam tiga kategori yaitu kategori tinggi, sedang, dan rendah. Sedangkan Objek pada penelitian ini adalah 
kemampuan pemecahan masalah matematis peserta didik dalam menyelesaikan soal cerita yang ditinjau dari langkah-langkah polya pada materi bangun ruang. Analisis data pada penelitian ini meliputi pengumpulan data, reduksi data, penyajian data, dan penarikan kesimpulan. Sedangkan teknik pengecekan keabsahan temuan dalam penelitian ini diantaranya meningkatkan ketekunan yang berarti melakukan pengamatan secara lebih cermat dan berkesinambungan serta melakukan triangulasi dalam pengujian kredibilitas data. Peneliti disini menggunakan triangulasi teknik yaitu berupa pengumpulan data yang berbeda-beda untuk mendapatkan data dari sumber yang sama kemudian melakukan pengecekan lebih lanjut.

\section{HASIL DAN PEMBAHASAN}

Hasil penelitian ini diuraikan berdasarkan data yang diperoleh dari penelitian yang dilaksanakan di MI Sains Al Hidayah, yaitu mengenai kemampuan pemecahan masalah matematis peserta didik dalam menyelesaikan soal cerita ditinjau dari langkah-langkah polya pada materi bangun ruang kelas VI. Pelaksanaan penelitian ini dilaksanakan dalam dua tahap, pertama yaitu pelaksanaan tes atau ujian tertulis kepada peserta didik dan kedua wawancara yang diadakan setelah pelaksanaan tes dilakukan.

Tabel 1. Tahap Pelaksanaan Penelitian

\begin{tabular}{cccc}
\hline Tahap & Subjek & $\begin{array}{c}\text { Hari/ } \\
\text { Tanggal }\end{array}$ & Tempat \\
\hline \multirow{2}{*}{ Tes } & $\begin{array}{c}\text { 6 orang peserta } \\
\text { didik kelas VI A }\end{array}$ & $\begin{array}{c}\text { Sabtu, 13 Juni } \\
\text { 2020 }\end{array}$ & $\begin{array}{c}\text { Rumah } \\
\text { Peserta Didik }\end{array}$ \\
\hline \multirow{2}{*}{$\begin{array}{c}\text { Wawan } \\
\text { cara }\end{array}$} & $\begin{array}{c}\text { 6 orang peserta } \\
\text { didik kelas VI A }\end{array}$ & $\begin{array}{c}\text { Selasa, 16 } \\
\text { Juni 2020 }\end{array}$ & $\begin{array}{c}\text { Rumah } \\
\text { Peserta Didik }\end{array}$ \\
\cline { 2 - 4 } & Guru Matematika & $\begin{array}{c}\text { Kamis, 18 } \\
\text { Juni 2020 }\end{array}$ & $\begin{array}{c}\text { Gedung MI } \\
\text { Al-Hidayah }\end{array}$ \\
\hline
\end{tabular}

Dalam menggali kemampuan

pemecahan masalah matematis peserta didik dalam menyelesaikan soal cerita, khususnya materi bangun ruang maka data akan diolah sesuai dengan teknik analisis data yang telah dikemukakan pada Bab III. Hal-hal yang akan diuraikan dalam temuan data ini yaitu hasil penelitian dalam bentuk deskripsi hasil tes.

Subjek dalam penelitian ini merupakan 6 orang peserta didik dari kelas VI A MI Sains Al Hidayah. Peneliti mengambil 6 subjek penelitian atas saran dari guru mata pelajaran matematika. Melalui teknik tersebut, peneliti memperoleh dua orang peserta didik dengan kemampuan tinggi, dua orang dengan kemampuan sedang, dan dua orang dengan kemampuan rendah. Setelah mengambil subjek yang akan diteliti kemudian peneliti melakukan tes kepada enam subjek tersebut dengan memberikan lima soal essay. Setelah tes dilakukan selanjunya peneliti mewawancarai keenam subjek penelitian tersebut. Tes soal cerita bangun ruang yang diberikan bertujuan untuk menganalisis kemampuan pemecahan masalah matematis peserta didik. Soal tes yang dirancang peneliti untuk menganalisis kemampuan pemecahan masalah matematis peserta didik menggunakan indikator : (1) Memahami Masalah (Understanding The Problem), (2) Menyusun Rencana Penyelesaian (Devising Plan), (3) Melaksanakan Rencana Penyelesaian (Carrying Out The Plan), dan (4) Mengecek Kembali (Looking Back).

Berdasarkan hasil tes dan wawancara yang telah dilakukan dapat disimpulkan bahwa subjek dalam kategori tinggi mampu dalam memahami masalah pada soal, merencanakan penyelesaian, serta menuliskan langkah-langkah dalam menyelesaikan soal, hanya saja masih terdapat kekeliruan dalam melakukan perhitungan sehingga jawabannya kurang tepat. Kemampuan pemecahan masalah matematis subjek kategori sedang terlihat dari cara mengerjakan soal cerita, mereka mengetahui apa yang diketahui dan 
ditanyakan dalam soal. Namun kemampuan mereka dalam menganalisis maksud atau yang diperintahkan dalam soal kurang diperhatikan sehingga mereka kurang tepat ketika menuliskannya pada lembar jawaban. Kemampuan pemecahan masalah matematis peserta didik sebenarnya bukan hanya terlihat pada kemampuan dalam membaca masalah saja akan tetapi yang perlu sekali diperhatikan yaitu kemampuan dalam memahami masalah. Sedangkan untuk subjek penelitian kategori rendah kemampuan membaca masalah, memahami masalah, dan kemampuan menuliskan jawaban penyelesaian soal cerita bangun ruang dari masih kurang. Terbukti dengan mereka merasa kesulitan menjawab pertanyaan dalam soal pada lembar jawabannya. Begitupun dengan mengkomunikasikan hasil jawabannya yaitu berdasarkan hasil wawancara antara peneliti dan subjek penelitian yang terlihat di atas. Kamampuan membaca, memahami masalah, dan menuliskan jawaban pada lembar jawaban peserta didik itu sangat penting karena kita dapat mengetahui kemampuannya dalam menyelesaikan soal cerita bangun ruang tersebut.

\section{Kemampuan pemecahan masalah matematis subjek kategori tinggi}

Berdasarkan hasil tes dan wawancara, kemampuan pemecahan masalah matematis subjek dengan kategori tinggi ini dapat dideskripsikan sebagai berikut : (1) pada indikator memahami masalah, subjek kategori ini telah mampu memahami masalah dengan baik dalam hal ini mereka paham dan mengerti terhadap apa yang diketahui dan yang ditanyakan dalam soal. (2) pada indikator menyusun rencana penyelesaian kedua subjek mampu membuat langkahlangkah penyelesaian yang sesuai dengan masalah dan menentukan rumus yang akan digunakan. (3) pada indikator melaksanakan rencana penyelesaian, kedua subjek dapat melaksanakan rencana dengan benar sesuai dengan langkah-langkah yang telah disusun. (4) pada indikator mengecek kembali, masih ditemukan kesalahan dalam perhitungan.

Berdasarkan hasil penelitian tersebut diperoleh data bahwa peserta didik berkemampuan tinggi termasuk dalam kategori mampu mencapai tiga indikator kemampuan pemecahan masalah, hal ini sejalan dengan temuan (Fajriah, 2019) subjek dengan kemampuan tinggi telah mampu memahami masalah, mampu merencanakan masalah, mampu menyelesaikan masalah, dan mengalami sedikit kesulitan dalam mengecek kembali hasil pekerjaannya.

\section{Kemampuan pemecahan masalah matematis subjek kategori sedang}

Berdasarkan hasil tes dan wawancara, kemampuan pemecahan masalah matematis subjek dengan kategori sedang ini dapat dideskripsikan sebagai berikut : (1) pada indikator memahami masalah, subjek kategori ini cukup mampu dalam memahami masalah dalam hal ini mereka cukup paham dan mengerti terhadap apa yang diketahui dan yang ditanyakan dalam soal. (2) pada indikator menyusun rencana penyelesaian, kedua subjek belum mampu membuat langkah-langkah penyelesaian yang sesuai dengan masalah. (3) pada indikator melaksanakan rencana penyelesaian, kedua subjek melaksanakan rencana namun belum melaksanakannya dengan benar karena langkah yang dibuat tidak sesuai dengan permasalahan yang ada pada soal (4) pada indikator mengecek kembali, kedua subjek melakukan pengecekan dengan memastikan benar atau tidaknya setiap langkah pengerjaan dan penggunaan rumus yang 
digunakan tetapi pada hasil tes tertulis masih terlihat bahwa subjek belum mampu menyusun rencana dengan benar karena belum mampu mencari konsep dan teori yang tepat untuk menyelesaikan soal.

Berdasarkan hasil penelitian tersebut diperoleh data bahwa peserta didik berkemampuan sedang hanya mampu mencapai dua indikator pemecahan masalah, hal ini sejalan dengan temuan (Indriyani, Nurcahyono, \& Agustiani, 2018) subjek dalam kategori sedang dapat mengidentifikasi masalah dengan baik pada beberapa soal saja, meskipun melaksanakan strategi penyelesaian yang salah namun subjek tidak melakukan kesalahan dalam operasi hitung.

\section{Kemampuan pemecahan masalah matematis subjek kategori rendah}

Berdasarkan hasil tes dan wawancara, kemampuan pemecahan masalah matematis subjek dengan kategori rendah ini dapat dideskripsikan sebagai berikut : (1) pada indikator memahami masalah, subjek kategori rendah ini belum mampu memahami masalah dalam hal ini mereka belum paham dan mengerti terhadap apa yang diketahui dan yang ditanyakan dalam soal. (2) pada indikator menyusun rencana penyelesaian, kedua subjek belum mampu membuat langkah-langkah penyelesaian yang sesuai dengan masalah. (3) pada indikator melaksanakan rencana penyelesaian, kedua subjek melaksanakan rencana namun belum melaksanakannya dengan benar karena langkah yang dibuat tidak sesuai dengan permasalahan yang ada pada soal (4) pada indikator mengecek kembali, kedua subjek mengatakan dalam sesi wawancara bahwa mereka melakukan pengecekan dengan memastikan benar atau tidaknya setiap langkah pengerjaan dan penggunaan rumus yang digunakan tetapi pada hasil tes tertulis masih terlihat bahwa subjek belum mampu memahami masalah, belum mampu menyusun rencana dengan benar dan masih terlihat beberapa kesalahan dalam perhitungan.

Berdasarkan hasil penelitian tersebut diperoleh data bahwa peserta didik berkemampuan rendah termasuk dalam kategori tidak mampu mencapai semua indikator kemampuan pemecahan masalah, hal ini sejalan dengan temuan (Hasanah, 2018) subjek dengan kemampuan rendah mengalami kesulitan dalam memahami masalah, subjek tidak menggunakan rumus yang sesuai, subjek tidak mampu menyelesaikan masalah dengan tepat serta tidak memeriksa kembali hasil pekerjaannya.

\section{KESIMPULAN}

Berdasarkan hasil analisis dan pembahasan di atas dapat ditarik kesimpulan sebagai berikut;

Kemampuan pemecahan masalah matematis peserta didik dalam kategori tinggi adalah peserta didik mampu dalam memahami masalah, mampu merencanakan penyelesaian, mampu menyelesaikan masalah, tetapi mengalami sedikit kesulitan dalam mengecek kembali.

Kemampuan pemecahan masalah matematis peserta didik dalam kategori sedang adalah peserta didik mampu dalam memahami masalah yaitu apa yang diketahui dan ditanyakan dalam soal, kurang mampu dalam merencanakan masalah, meskipun salah dalam melaksanakan rencana penyelesaian namun tidak melakukan kesalahan perhitungan, dan belum mampu dalam melihat kembali hasil penyelesaiannya.

Kemampuan pemecahan masalah peserta didik dalam kategori rendah adalah 
peserta didik belum mampu memahami masalah, merencanakan penyelesaian, melakukan rencana penyelesaian dan melihat kembali hasil penyelesaiannya dalam menyelesaikan soal cerita bangun ruang.

\section{DAFTAR RUJUKAN}

Dewi, A. (2013). Analisis Kemampuan Menyelesaikan Soal Cerita Matematika Tentang Bangun Datar Ditinjau Dari Teori Van Hiele. 2(4), 481-494.

Fajriah, W. (2019). Analisis Kemampuan Pemecahan Masalah Peserta Didik yang Belajar Dengan Strategi Problem Solving Berdasarkan Langkah Polya. Math Educa Journal, 3(1), 57-70.

Hasanah, F. N. (2018). Analisis Kemampuan Pemecahan Masalah dalam Menyelesaikan Soal Cerita Matri Segi Empat dan Segitiga Kelas VII SMP Negeri 1 Gatik Tahun Ajaran 2017/2018. Jurnal Pendidikan, 1(1), 11-12

Indonesia， P. R. (2003). Undang-Undang Republik Indonesia Nomor 20 Tahun 2003 Tentang Sistem Pendidikan Nasional

Indriyani, F., Nurcahyono, N. A., \& Agustiani, N. (2018). Analisis Kemampuan Pemecahan Masalah Siswa Berdasarkan Langkah Ideal Problem Solving. PYTHAGORAS: Jurnal Program Studi Pendidikan Matematika, 7(2), 56-67.
Mursalin. (2016). Pembelajaran Geometri Bidang Datar Di Sekolah Dasar Berorientasi Teori Belajar Piaget. Jurnal Dikma, 4(2), 250-258.

Nafi'an, M. I. (2011). Kemampuan Siswa Dalam Menyelesaikan Soal Cerita. Jurnal Pendidikan, 3(7), 978-979.

Siagian, M. D. (2016). Kemampuan koneksi matematik dalam pembelajaran matematika. MES: Journal of Mathematics Education and Science, 2(1).

Sugiyatmi, S. (2012). Kepemimpinan Kepala Sekolah Di SD Gugus Asmorodono Kecamatan Jebres Kota Surakarta (Studi Multi Situs di SD Negeri Sibela Timur dan SDIT Lukman Hakim). Jurnal Pendidikan, 2(1), 6

Utami, R. W., Endaryono, B. T., \& Djuhartono, T. (2018). Kemampuan Peserta Didik dalam Menyelesaikan Soal Cerita Matematika. Faktor: Jurnal Ilmiah Kependidikan, 5(3), 187-192.

Polya, Geroge. 1973. How to Solve It. Princeton University Press. New Jersey

WARDHANI, I. S. (2015). MENUMBUHKAN KEMAMPUAN BERFIKIR GEOMETRI MELALUI PEMBELAJARAN CONNECTED MATHEMATICS PROJECT (CMP) Menumbuhkan Kemampuan Berfikir Geometri melalui Pembelajaran Connected Mathematics Project (CMP). Jurnal Pendidikan dan Pembelajaran Anak Sekolah Dasar, 1(01). 